\title{
Immunocytochemical Localization of Thioredoxins in the Cyanobacteria Anabaena cylindrica and Anabaena variabilis
}

\author{
By J. D. COSSAR, $\dagger$ A. J. DARLING, S. M. IP, $\ddagger$ P. ROWELL* \\ AND W. D. P. STEWART \\ AFRC Research Group on Cyanobacteria and Department of Biological Sciences, \\ University of Dundee, Dundee DDI $4 H N$, UK
}

(Received 25 March 1985; revised 2 July 1985)

Colloidal gold conjugated goat anti-rabbit IgG and specific antisera raised against purified thioredoxins from Anabaena cylindrica and Anabaena variabilis have been used to determine the localization of thioredoxin in whole filaments of $A$. cylindrica and A. variabilis. Vegetative cells of $A$. cylindrica were labelled differently when tested with either of the two anti-thioredoxin sera. The anti- $A$. cylindrica thioredoxin serum reacted only with $A$. cylindrica thioredoxin which was located predominantly in the nucleoplasm in vegetative cells; it showed no association with the chromatoplasm. Anti-A variabilis thioredoxin serum labelled vegetative cells of $A$. variabilis, particularly in the vicinity of the thylakoid membranes and also labelled $A$. cylindrica in the vicinity of the thylakoid membranes, indicating that a second thioredoxin or thioredoxin-like protein was present in this cyanobacterium. Heterocysts of $A$. cylindrica and $A$. variabilis showed substantially less labelling than vegetative cells when tested with both antisera.

\section{INTRODUCTION}

Heterocysts, which usually account for 5 to $8 \%$ of the cells present in $\mathrm{N}_{2}$-fixing heterocystous cyanobacteria, are the sites of $\mathrm{N}_{2}$-fixation under aerobic conditions (see Stewart, 1980). There is controversy as to whether they are the sole sites of nitrogenase activity under strictly anaerobic conditions (Fleming \& Haselkorn, 1974; Murry et al., 1984). Heterocysts are also the main site of assimilation, via glutamine synthetase, of newly fixed $\mathrm{NH}_{4}^{+}$(Dharmawardene et al., 1973; Thomas et al., 1977; see also Stewart, 1980). However, heterocysts lack photosystem 2 activity (see Tel-Or \& Stewart, 1977; Ho \& Krogmann, 1982) and do not synthesize ribulose-1,5bisphosphate carboxylase/oxygenase, the key carboxylating enzyme of the Calvin cycle (see Cossar et al., 1985). The oxidative pentose phosphate pathway enzyme glucose-6-phosphate dehydrogenase is present and active in the light and dark, in contrast to vegetative cells where it is fully active only in the dark (Apte et al., 1978).

To date, information on the distribution of proteins between vegetative cells and heterocysts (Lex \& Carr, 1974; Winkenbach \& Wolk, 1973; Apte et al., 1978; Neuer et al., 1983) has depended on the use of techniques of heterocyst isolation which involve selective disruption of vegetative cells. The main drawbacks of such techniques are that the heterocysts are at various stages of maturity and it is difficult to assess their 'intactness' and the degree of vegetative cell contamination. Here we have used an immunocytochemical technique which uses specific antisera and colloidal gold in order to determine the intracellular location of thioredoxins (see Horisberger, 1983) in vegetative cells and heterocysts of Anabaena cylindrica and Anabaena variabilis.

† Present address: Institut für Botanische, Biologie und Phytochemie, Universität Freiburg Schweiz, 3 Rue Albert-Gockel, CH-1700, Freiburg, Switzerland.

$\ddagger$ Present address: Department of Biochemistry, University of St Andrews, St Andrews, UK. 


\section{METHODS}

Organisms and grow'th conditions. Axenic cultures of Anabaena cylindrica Lemm. (CCAP 1403/2a) and Anabaena variabilis Kütz. (ATCC 29413) were grown in nitrogen-free BG-11 medium (Stanier et al., 1971) in 10-litre continuous cultures at a dilution rate of $0.005 \mathrm{~h}^{-1}$ at $25^{\circ} \mathrm{C}$, at a photon flux density of $120 \mu \mathrm{mol} \mathrm{m}^{-2} \mathrm{~s}^{-1}$, incident at the surface of the vessel, and gassed with air at a rate of 1 litre $\mathrm{min}^{-1}$.

Preparation of antisera. Antisera against purified thioredoxins from A. cylindrica and A. tariabilis were raised in New Zealand White rabbits as described previously (Ip et al., 1984). On the basis of amino acid sequence data, both thioredoxins were structurally similar to thioredoxin $m$ rather than to thioredoxin $f$ of chloroplasts (Tsugita $e t$ al., 1983).

Immunocytochemical labelling studies. The method used was a modification of that described by Beesley et al. (1984). Cyanobacteria were harvested by centrifugation at $12000 \mathrm{~g}$ for $1 \mathrm{~min}$, resuspended in $2.5 \%$ (v/v) glutaraldehyde in $0.1 \mathrm{M}$-potassium phosphate buffer $(\mathrm{pH} 7.2)$ and incubated for $2 \mathrm{~h}$ at $20^{\circ} \mathrm{C}$. Excess glutaraldehyde was removed by washing three times for $15 \mathrm{~min}$ each in $0.1 \mathrm{M}$-potassium phosphate buffer (pH 7.2). The samples were then dehydrated in a graded ethanol series and embedded in LR 'white' resin (London Resin Co., Basingstoke, UK). Thin sections were cut using a Reichert OMU3 ultramicrotome and floated on to 300 mesh gold grids. Except where indicated in the figure legend, sections were then incubated for $2 \mathrm{~h}$ at room temperature in a $2 \%(\mathrm{v} / \mathrm{v})$ dilution of the specific antiserum (concentrations of undiluted antisera were $10.0 \mathrm{mg} \mathrm{ml}^{-1}$ for serum Ac and $18.5 \mathrm{mg} \mathrm{ml}^{-1}$ for serum Av) in $50 \mathrm{~mm}$-Tris/ $\mathrm{HCl}$ buffer $(\mathrm{pH} 7.4)$ containing $1 \%$ $(\mathrm{v} / \mathrm{v})$ Tween $20,1 \%(\mathrm{w} / \mathrm{v})$ bovine serum albumin and $0.2 \%(\mathrm{w} / \mathrm{v})$ gelatin, washed for $20 \mathrm{~min}$ in water containing $0.02 \%(w / v) ~ K C l$, and incubated for $1 \mathrm{~h}$ on drops of $5 \mathrm{~nm}$ or $20 \mathrm{~nm}$ colloidal gold (approximately $10^{12}$ particles $\mathrm{ml}^{-1}$ ) conjugated to goat anti-rabbit IgG (GAR G5 and GAR G20, respectively) (Janssen Pharmaceutical, Beerse, Belgium). The sections were then washed for $20 \mathrm{~min}$ in water containing $0.02 \%(\mathrm{w} / \mathrm{v}) \mathrm{K} \mathrm{Cl}$, dried in air and stained for $20 \mathrm{~h}$ in osmium tetroxide vapour at $20^{\circ} \mathrm{C}$. For control treatments, pre-immune rabbit serum was used instead of the specific antiserum. Sections were examined using an Associated Electrical Industries EM801 transmission electron microscope.

\section{RESULTS}

\section{Localization of thioredoxin in A. variabilis}

Vegetative cells of $A$. variabilis were extensively labelled, particularly in the vicinity of the thylakoids, when treated with antiserum against pure $A$. variabilis thioredoxin (serum Av) (Fig. $(a-c)$. The labelling of heterocysts was always lower than that of adjacent vegetative cells (Fig. $1 b, c)$ and was sometimes negligible (Fig. $1 c$ ). This labelling was affected by the concentration of antiserum used and by the length of time during which the samples were exposed to the antiserum, and it varied also with the morphological state of the heterocyst, decreasing with heterocyst age.

Antiserum against pure $A$. cylindrica thioredoxin (serum Ac) did not react with cell-free extracts of $A$. variabilis on rocket immunoelectrophoresis (Ip et al., 1984). Labelling of $A$. variabilis cells with this antiserum was similar to that obtained with pre-immune serum (data not shown), confirming the lack of cross-reactivity between $A$. variabilis thioredoxin and serum Ac.

\section{Localization of thioredoxin in A. cylindrica}

Vegetative cells of $A$. cylindrica were extensively labelled when treated with serum Ac (Fig. 2) particularly in the nucleoplasmic region (Fig. $2 a-c, f$ ). Again, the labelling in the heterocysts (Fig. $2 d, e$ ) decreased with heterocyst age and labelling of some mature heterocysts (Fig. $2 d$ ) was no different from that obtained with pre-immune serum (Fig. $3 h$ ). Labelling of developing heterocysts (Fig. $2 e$ ) was similar to that of vegetative cells (Fig. $2 a-c, f$ ).

Fig. 3 shows the results obtained when $A$. cylindrica cells were treated with serum Av. In contrast to serum Ac, labelling was almost exclusively associated with the chromatoplasm (Fig. $3 a-d$ ). Again, however, the labelling of heterocysts (Fig. $3 f, g$ ) was always lower than that of vegetative cells, and was higher than that obtained with pre-immune serum (Fig. $3 e, h$ ). Under the labelling conditions used in these experiments, there was extensive binding of antisera to the heterocyst envelope of $A$. cylindrica. This was attributed to non-specific binding of immunoglobulins since labelling was equally extensive whether specific antisera (Fig. $2 d, e$; Fig. $3 f, g$ ) or pre-immune sera (Fig. $3 h$ ) were used. 

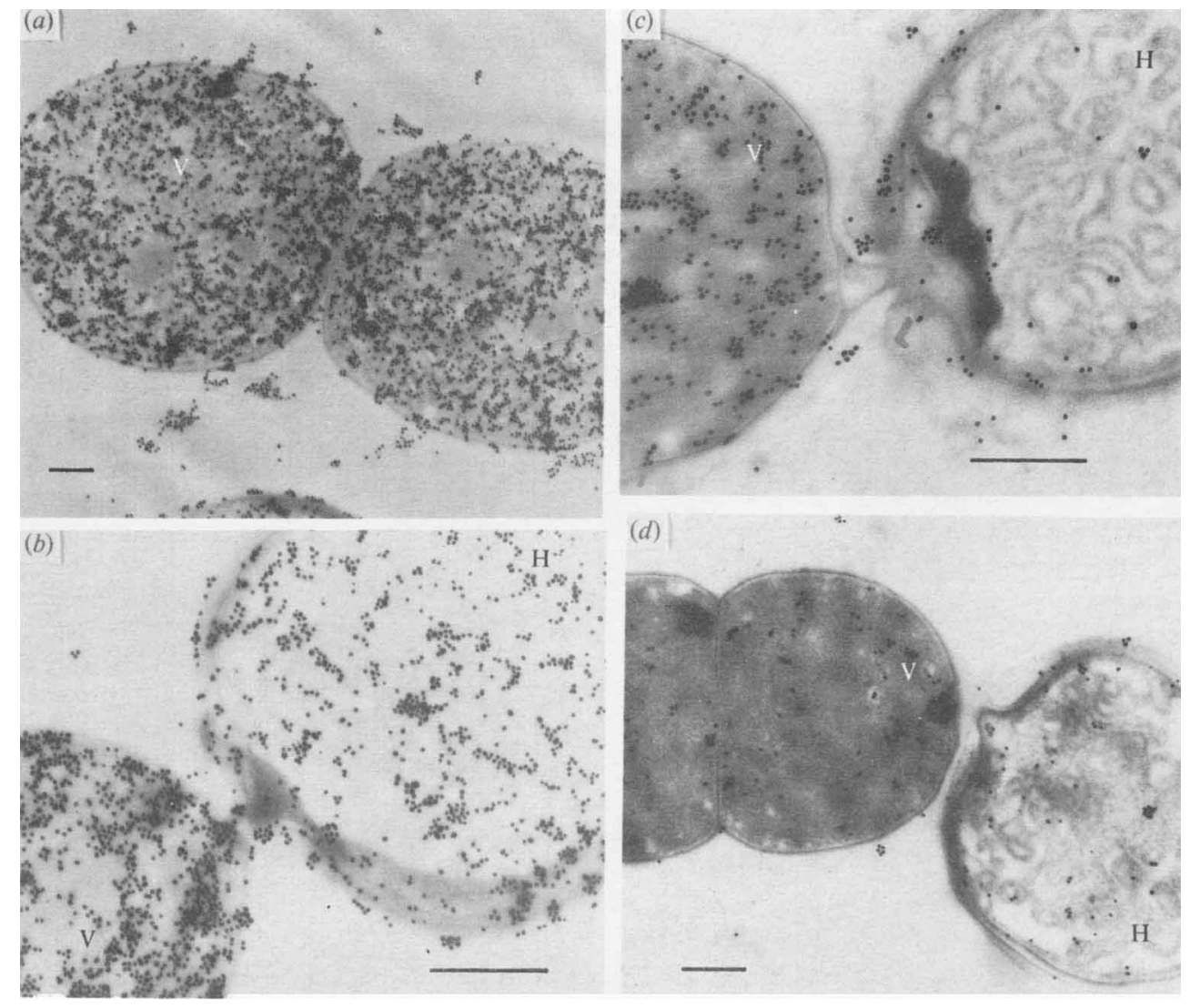

Fig. 1. Localization of thioredoxin in Anabacna rariahilis. Sections were labelled with GAR G20 following treatment with anti-A cariabilis thioredoxin serum $(2 \%, \mathrm{v} / \mathrm{v})$ for $2 \mathrm{~h}$ at room temperature $(a$, b), at a higher concentration $\left(10_{0}^{\circ}, \mathrm{v} / \mathrm{v}\right)$ for $18 \mathrm{~h}$ at $4{ }^{\circ} \mathrm{C}(c)$ or with pre-immune serum $(2 \%, v / v)(d)$. V, vegetative cell: $\mathrm{H}$, heterocyst: bars, $0.5 \mu \mathrm{m}$.

\section{DISCUSSION}

We have purified a single, soluble thioredoxin from the cyanobacteria $A$. cylindrica and $A$. variabilis. Each of these thioredoxins was identified on the basis of its ability to activate several enzymes, including NADP ${ }^{+}$-dependent malate dehydrogenase and fructose-1,6-bisphosphatase, and to deactivate glucose-6-phosphate dehydrogenase (see Buchanan, 1980; Cossar et al., 1984). On the basis of their partial amino acid sequences, the thioredoxins from $A$. cylindrica and A. variabilis (Ip et al., 1984; A. J. Darling, P. Rowell \& W. D. P. Stewart, unpublished results) are structurally similar to other bacterial thioredoxins (Holmgren, 1968; Meng \& Hogenkamp, 1981 ) and to chloroplast thioredoxin $m$ (Tsugita et al., 1983), but they differ in some other respects including their antigenicity (our unpublished results).

The labelling patterns of $A$. cylindrica with the two antisera (Ac and Av) strongly suggest the presence of two different thioredoxins or thioredoxin-like proteins in this organism as in certain other cyanobacteria (Schmidt, 1980; Yee et al., 1981: Whittaker \& Gleason, 1984) and that these may have different intracellular and intercellular locations. The major thioredoxin (see Ip et al., 1984), with which serum Ac reacts, is a nucleoplasmic protein which occurs in vegetative cells but which may be absent from, or present at very much reduced levels in mature heterocysts. It resembles, in some respects, thioredoxin of Escherichia coli which occurs mainly in association with the plasmalemma/periplasmic space and in the nuclear region (Lunn \& Pigiet, 1982; 

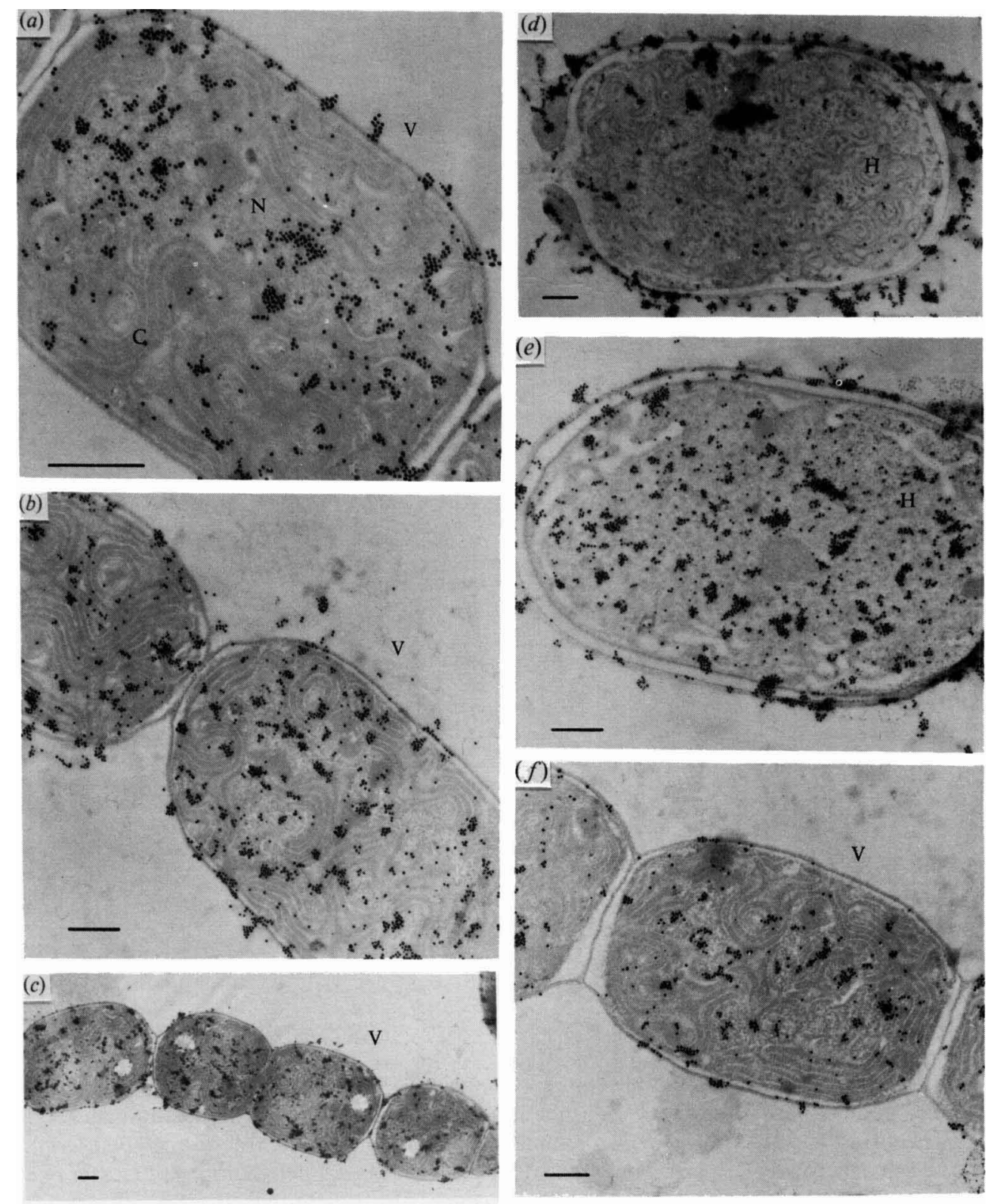

Fig. 2. Localization of thioredoxin in Anabaena cylindrica using anti- $A$. cylindrica thioredoxin serum $(a-f)$. Sections were labelled with GAR G20 following pre-treatment with the anti-A. cylindrica thioredoxin serum $(2 \%, \mathrm{v} / \mathrm{v})$ for $2 \mathrm{~h}$ at room temperature. $\mathrm{V}$, vegetative cell; $\mathrm{H}$, heterocyst; $\mathrm{N}$, nucleoplasm; C, chromatoplasm; bars, $0.5 \mu \mathrm{m}$.

Nygren et al., 1982). The other, which reacts with serum Av, is associated with the chromatoplasm of vegetative cells and is present at reduced levels in heterocysts. Serum Av does not react with purified thioredoxin from $A$. cylindrica (Ip et al., 1984) on rocket immunoelectrophoresis, but we have recently also purified a minor thioredoxin-like protein which appears to correspond to the protein with which serum Av reacts in the chromatoplasm of both $A$. cylindrica and $A$. variabilis. A thylakoid membrane-associated thioredoxin has previously been reported from chloroplasts (Ashton et al., 1980). 

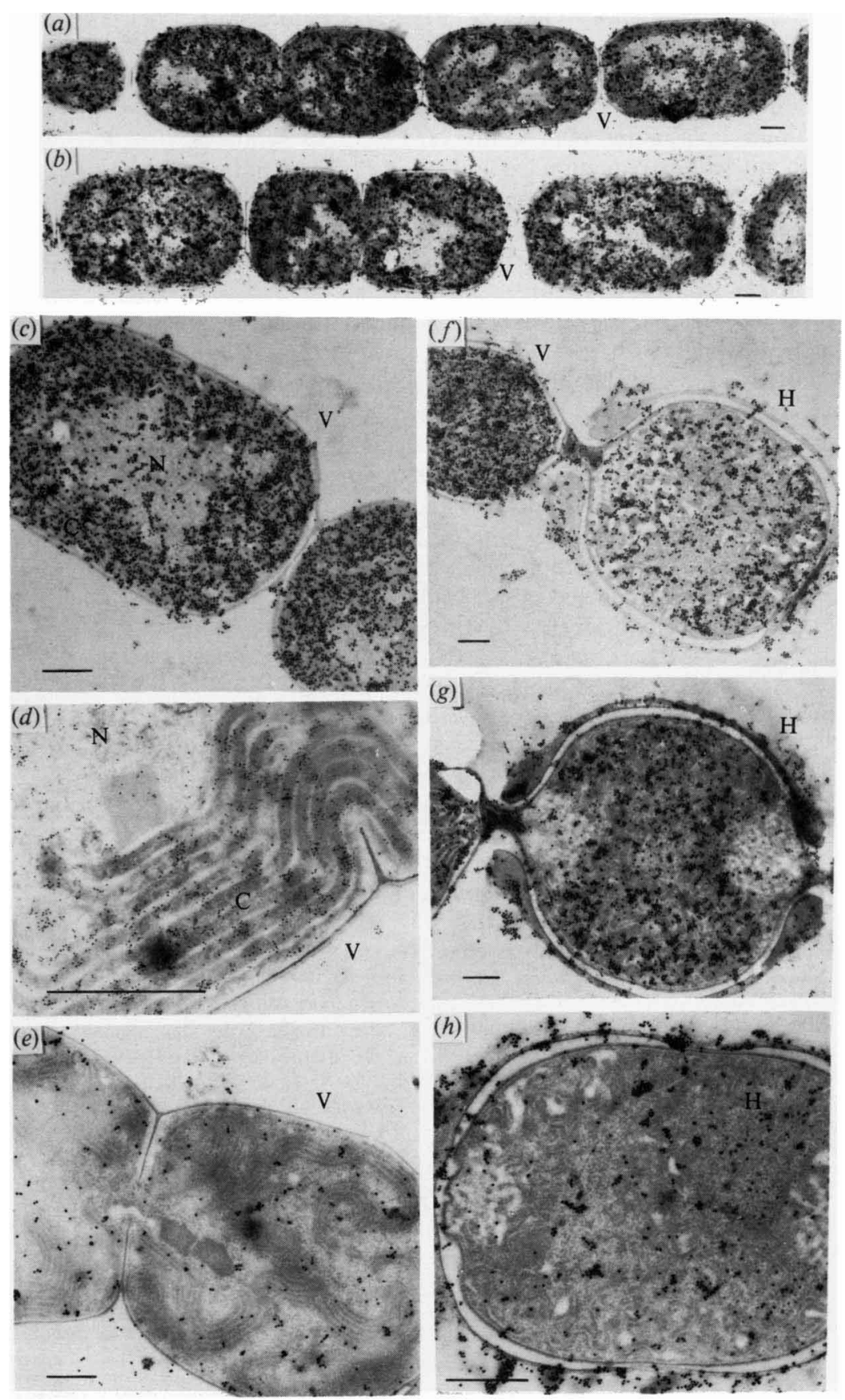

Fig. 3. Localization of thioredoxin in Anabaena cylindrica using anti-A. variabilis thioredoxin serum. Sections were labelled with GAR G20 $(a-c, e-h)$ or GAR G5 $(d)$ following treatment with anti-A. variabilis thioredoxin serum $(2 \%, \mathrm{v} / \mathrm{v})(a-d, f, g)$ or pre-immune serum $(2 \%, \mathrm{v} / \mathrm{v})(e, h)$. V, vegetative cell; $\mathrm{H}$, heterocyst; $\mathrm{N}$, nucleoplasm; $\mathrm{C}$, chromatoplasm; bars, $0.5 \mu \mathrm{m}$. 
The true physiological functions of cyanobacterial thioredoxins are incompletely understood at present. It is possible that the chromatoplasm-associated thioredoxin(s) are involved in the modulation of the activities of Calvin cycle enzymes (see Buchanan, 1980; Yee et al., 1981), the coupling factor of photophosphorylation (Mills et al., 1981), and of glucose-6-phosphate dehydrogenase (Cossar et al., 1984). The soluble thioredoxin of $A$. cylindrica, on the other hand, which is structurally similar to $E$. coli thioredoxin (Holmgren, 1968; Ip et al., 1984), is located mainly in the nucleoplasm and may be involved in DNA synthesis as in $E$. coli where it may function in ribonucleotide reduction (Laurent et al., 1964). Thioredoxin is also required for the functioning of DNA polymerase of bacteriophage $T_{7}$ (Mark \& Richardson, 1976; Mark et al., 1977 ) and possibly in plasmid replication in E. coli (Lunn et al., 1984). The apparent absence of this thioredoxin from heterocysts may be associated with the inability of mature heterocysts to de-differentiate (Wilcox et al., 1973).

We have demonstrated previously that reduced thioredoxin can deactivate glucose-6phosphate dehydrogenase of $A$. variabilis (Cossar et al., 1984; see also Udvardy et al., 1984). This may be important in vegetative cells for the inhibition of the oxidative pentose phosphate pathway in the light (Pelroy et al., 1972; Duggan \& Anderson, 1975; Apte et al., 1978). We have further postulated (Stewart et al., 1985) that the decreased level of thioredoxins in heterocysts of $A$. cylindrica and $A$. variabilis may be related to the high activity of glucose-6-phosphate dehydrogenase in such cells, thus allowing reciuctant for nitrogenase to be provided by the oxidative pentose phosphate pathway both in the light and dark (Stewart et al., 1985). Further evidence, for or against this hypothesis, necessitates an examination for both thioredoxin and nitrogenase proteins in single heterocysts. Studies are in progress to determine more precisely the correlation of thioredoxin levels with the stages of differentiation of heterocysts.

We thank the Agricultural and Food Research Council, the Science and Engineering Research Council, the Natural Environment Research Council and the Royal Society for financial support. We are indebted to Dr Julian Beesley, Wellcome Research Co., Beckenham, Kent, for assisting with the immunocytochemical labelling method. We also thank Mrs E. M. Lloyd-Davies for help with the electron microscopy.

\section{REFERENCES}

APte, S. K., Rowell, P. \& Stewart, W. D. P. (1978). Electron donation to ferredoxin in heterocysts of the $\mathrm{N}_{2}$-fixing alga Anabaena cylindrica. Proceedings of the Royal Society B200, 1-25.

Ashton, A. R., Brennan, T. \& Anderson, L. E. (1980). Thioredoxin-like activity of thylakoid membranes. Thioredoxin catalysing the reductive inactivation of glucose-6-phosphate dehydrogenase occurs in both soluble and membrane bound form. Plant Physiology 66, 605-608.

Beesley, J. E., DAy, S. E. J., BetTS, M. P. \& ThORLEY, C. M. (1984). Immunocytochemical labelling of Bacteroides nodosus pili using an immunogold technique. Journal of General Microbiology 130, 14811487.

BUCHANAN, B. B. (1980). Role of light in the regulation of chloroplast enzymes. Annual Review of Plant Physiology 31, 341-374.

Cossar, J. D., Rowell, P. \& Stewart, W. D. P. (1984). Thioredoxin as a modulator of glucose-6phosphate dehydrogenase in a $\mathrm{N}_{2}$-fixing cyanobacterium. Journal of General Microbiology 130, 991998.

Cossar, J. D., Rowell, P., Darling, A. J., Murray, S., Codd, G. A. \& Stewart, W. D. P. (1985). Localization of ribulose-1,5-bisphosphate carboxylase/oxygenase in the $\mathrm{N}_{2}$-fixing cyanobacterium
Anabaena cylindrica. FEMS Microbiology Letters 28, 65-68.

Dharmawardene, M. W. N., Haystead, A. \& STEWART, W. D. P. (1973). Glutamine synthetase of the nitrogen-fixing alga Anabaena cylindrica. Archiv für Mikrobiologie 90, 281-295.

DugGan, J. X. \& Anderson, L. E. (1975). Light regulation of enzyme activity in Anacystis nidulans (Richt). Planta 122, 293-297.

Fleming, H. \& HASELKORN, R. (1974). The program of protein synthesis during heterocyst differentiation in nitrogen-fixing blue-green algae. Cell 3, 159-170.

Ho, K. K. \& Krogmann, D. W. (1982). Photosynthesis. In The Biology of Cyanobacteria, pp. 48-75. Edited by N. G. Carr \& B. A. Whitton. Oxford: Blackwell Scientific Publications.

Holmgren, A. (1968). Thioredoxin 6. The amino acid sequence of the protein from Escherichia coli B. European Journal of Biochemistry 6, 475-487.

HORISBERGER, M. C. (1983). Colloidal gold as a tool in molecular biology. Trends in Biochemical Sciences $\mathbf{8}$, 395-397.

IP, S.-M., Rowell, P., Aitken, A. \& Stewart, W. D. P. (1984). Purification and characterization of thioredoxin from the $\mathrm{N}_{2}$-fixing cyanobacterium, Anabaena cylindrica. European Journal of Biochemistry 141, 497-504. 
Laurent, T. C., Moore, E. C. \& Reichard, P. (1964). Enzymatic synthesis of deoxyribonucleotides. IV. Isolation and characterization of thioredoxin, the hydrogen donor, from Escherichia coli B. Journal of Biological Chemistry 239, 3436-3444.

LEX, M. \& CARR, N. G. (1974). The metabolism of glucose by heterocysts and vegetative cells of Anabaena cylindrica. Archives of Microbiology 101, 161-167.

LunN, C. A. \& Pigiet, V. P. (1982). Localization of thioredoxin from Escherichia coli in an osmotically sensitive compartment. Journal of Biological Chemistry 257, 11424-11430.

Lunn, C. A., Kathuus, S., Wallace, B. J., Kushner, S. R. \& PigieT, V. P. (1984). Amplification and purification of plasmid-encoded thioredoxin from Escherichia coli K12. Journal of Biological Chemistry 259, 10469-10474.

MARK, D. F. \& Richardson, C. C. (1976). Escherichia coli thioredoxin: a subunit of bacteriophage T7 DNA polymerase. Proceedings of the National Academy of Sciences of the United States of America 73, 780-784.

Mark, D. F., Chase, J. W. \& Richardson, C. C. (1977). Genetic mapping of $\operatorname{tr} x A$, a gene affecting thioredoxin in Escherichia coli K12. Molecular and General Genetics 155, 145-152.

Meng, M. \& Hogenkamp, H. R. C. (1981). Purification, characterization and amino acid sequence of thioredoxin from Cornyebacterium nephridii. Journal of Biological Chemistry 256, 9174-9182.

Mills, J. D., Mitchell, P. \& Schurmann, P. (1981). The role of thioredoxin in the modulation of coupling factor ATPase activity, in intact chloroplasts. In Photosynthesis II. Electron Transport and Photophosphorylation, pp. 839-848. Edited by G. Akoyonoglou. Philadelphia: Balaban.

Murry, M. A., Hallenbeck, P. C. \& Benemann, J. R. (1984). Immunochemical evidence that nitrogenase is restricted to the heterocysts in Anabaena cylindrica. Archives of Microbiology 137, 194-199.

Neuer, G., PAPEN, H. \& Bothe, H. (1983). Heterocyst biochemistry and differentiation. In Photosynthetic Prokaryotes: Cell Differentiation and Function, pp. 219-242. Edited by G. C. Papageorgiou \& L. Packer. New York, Amsterdam \& Oxford: Elsevier Biomedical.

Nygren, H., Rozell, B., Holmgren, A. \& Hansson, H.-A. (1982). Immunoelectron microscopic localization of glutaredoxin and thioredoxin in Escherichia coli cells. FEBS Letters 133, 145-150.

Pelroy, R. A., RippKa, R. \& Stanier, R. Y. (1972). The metabolism of glucose by unicellular blue-green algae. Archiv für Microbiologie 87, 303-322.
SCHMIDT, A. (1980). Isolation of two thioredoxins from the cyanobacterium Synechococcus 6301. Archives of Microbiology 127, 259-265.

Stanier, R. Y., Kunisawa, R., Mandel, M. \& CohenBAZIRE, G. (1971). Purification and properties of unicellular blue-green algae (order Chroococcales). Bacteriological Reviews 35, 171-205.

STEWART, W. D. P. (1980). Some aspects of structure and function in $\mathrm{N}_{2}$-fixing cyanobacteria. Annual Review of Microbiology 34, 497-536.

Stewart, W. D. P., Rowell, P., Cossar, J. D. \& Kerby, N. W. (1985). Physiological studies on $\mathrm{N}_{2^{-}}$ fixing cyanobacteria. In Nitrogen Fixation and $\mathrm{CO}_{2}$ Metabolism, pp. 269-279. Edited by P. W. Ludden \& J. E. Burris. New York: Elsevier.

Tel-Or, E. \& Stewart, W. D. P. (1977). Photosynthetic components and activities of nitrogen-fixing isolated heterocysts of Anabaena cylindrica. Proceedings of the Royal Society B198, 61-86.

Thomas, J., Meeks, J. C., Wolk, C. P., Shaffer, P. W., Austin, S. M. \& Chien, W.-S. (1977). Formation of glutamine from ${ }^{13} \mathrm{~N}$ ammonia, ${ }^{13} \mathrm{~N}$ dinitrogen, and ${ }^{14} \mathrm{C}$ glutamate by heterocysts isolated from Anabaena cylindrica. Journal of Bacteriology 129, 1545-1555.

Tsugita, A., Maeda, K. \& SchurmanN, P. (1983). Spinach chloroplast thioredoxins in evolutionary drift. Biochemical and Biophysical Research Communications 115, 1-7.

Udvardy, J., Borbely, G., Juhasz, A. \& Farkas, G. L. (1984). Thioredoxin and redox modulation of glucose 6-phosphate dehydrogenase in Anabaena sp. 7120 vegetative cells and heterocysts. Journal of Bacteriology 157, 681-683.

WhitTAKer, M. M. \& Gleason, F. K. (1984). Isolation and characterization of thioredoxin $f$ from the filamentous cyanobacterium, Anabaena sp. 7119. Journal of Biological Chemistry 259, 14088-14093.

Wilcox, M., Mitchison, G. J. \& SMith, R. J. (1973). Pattern formation in the blue-green alga Anabaena. II. Controlled proheterocyst regression. Journal of Cell Science 13, 637-649.

Winkenbach, F. \& Wolk, C. P. (1973). Activities of enzymes of the oxidative and the reductive pentose phosphate pathways in heterocysts of a blue-green alga. Plant Physiology 52, 480-483.

Yee, B. C., De la Torre, A., Crawford, N. A., Lara, C., Carlson, D. E. \& Buchanan, B. B. (1981). The ferredoxin-thioredoxin system of enzyme regulation in a cyanobacterium (Nostoc muscorum). Archives of Microbiology 130, 14-18. 